\title{
Sistem Pengawasan Keuangan Badan Usaha Milik Desa (BUM Des) berbasis Android
}

\author{
Lia Farokhah $^{\# 1}$, Yudistira Arya Sapoetra ${ }^{\# 2}$ \\ "Program Studi Informatika, STMIK ASIA Malang \\ Jalan Soekarno Hatta-Rembuksari $1 A$ \\ farokhaheasia.ac.id \\ ${ }^{2}$ yudistiraarya@gmail.com
}

\begin{abstract}
Abstrak-Program pemerintah untuk peningkatan potensi desa dalam bentuk badan usaha milik desa (BUM Des) sedang digalakkan dengan serius. Pemerintah menganggap ini adalah salah satu cara mengentaskan kemiskinan dengan cara peningkatkan kesejahteraan dan memandirikan desa secara keuangan. Namun, ada banyak masalah yang ada di lapangan seperti kekurang percayaan pengurus internal BUM Des sendiri terhadap kelembagaan BUM Des. Hal ini menyebabkan banyak desa yang ragu dalam mendirikan BUM Des atau BUM Des yang sudah berdiri namun tidak berkembang. Masalah transparansi merupakan masalah yang paling utama dalam kelembagaan BUM Des. Sistem kepercayaan, pengelolaan dan transparansi keuangan serta pembagian hasil hasil usaha yang menjadi pokok tujuan hampir setiap BUM Des yaitu kesejahteraan. Dalam perancangan aplikasi pengawasan keuangan BUM Des mendapatkan hasil umpan balik sebesar sebesar $82,77 \%$. Hal ini menunjukkan hasil umpan balik yang dianggap sangat positif terhadap aplikasi sistem pengawasan BUM Des dengan pengujian responden dari desa yang sudah terbentuk BUM Des maupun desa yang masih ragu-ragu dalam pendirian BUM Des karena permasalahan transparansi keuangan.
\end{abstract}

Kata kunci - BUM Des, Transparansi, Aplikasi, Keuangan

\section{PENDAhUlUan}

Bumdes atau Badan usaha milik desa, adalah usaha pemerintah dalam pemberantasan kemiskinan. Bumdes dilandasi oleh aturan UU Nomor 32 Tahun 2004 tentang pemerintah daerah pasal 213 ayat 1[1]. Bumdes dibentuk berbadan hukum, ditetapkan dengan peraturan desa, dan dikelola oleh pemerintah desa. Bumdes dibentuk sesuai dengan kebutuhan dan potensi yang ada di masing-masing desa.

Sesuai dengan data Badan Pusat Statistik tahun 2016 tentang prosentase penduduk miskin, tingkat kemiskinan di desa lebih tinggi dibandingkan di kota[2]. Sejatinya desa memiliki banyak potensi yang bernilai tinggi dibandingkan di kota, namun beberapa permasalahan yang terjadi di daerah pedesaan adalah rendahnya manajemen dari potensi yang ada di pedesaan terutama potensi sumber daya alam, waktu, cost atau biaya yang murah serta beberapa faktor lainnya.

Disisi lain, pemerintah pusat berusaha untuk meningkatkan potensi tersebut agar semakin menekan tingkat kemiskinan dengan menggelontorkan dana yang ditujukan kepada Badan usaha milik desa (Bum des). Banyak desa yang tertarik untuk mendirikan BUM Des namun permasalahan muncul dari segi kelembagaan, permodalan dan sumber daya [3]. Sisi kelembagaan sendiri merupakan salah satu masalah paling utama dalam pendirian atau operasisonal BUM Des. Permasalahan kelembagaan internal seperti sistem kepercayaan, pengelolaan dan transparansi keuangan serta pembagian hasil hasil usaha yang menjadi pokok tujuan hampir setiap BUM Des yaitu kesejahteraan. Hal tersebut mempengaruhi dalam pendirian BUM Des.

Berdasarkan uraian permasalahan diatas, agar usaha pemerintah yang melibatkan desa dapat berjalan dengan baik dan dana yang diberikan dapat terkontrol serta internal pengurus BUM Des dan desa menjadi nyaman serta profesional dalam bekerjasama maka dibentuklah sebuah sistem yang dapat mengatasi masalah transparansi sehingga semua elemen bisa bekerja maksimal demi kesejahteraan bersama. Penelitian ini juga menjawab tentang saran penelitian sebelumnya tentang aplikasi Bum Des dimana didalamnya masih terdapat kelemahan dalam sistem pengawasan dan transparansi[4]

\section{URAIAN PENELITIAN}

Badan Usaha Badan Usaha Milik Desa (BUMDes) adalah lembaga usaha desa yang dikelola oleh masyarakat dan pemerintahan desa dalam upaya memperkuat perekonomian desa dan dibentuk berdasarkan kebutuhan dan potensi desa[5].BUMDes memiliki tujuan dalam menyediakan layanan kebutuhan bagi usaha produktif diutamakan untuk masyarakat desa yang tergolong kelompok miskin, 
mengurangi adanya praktek rentenir dan pelepasan uang. Selain itu pula tujuan didirikan BUMDes adalah menciptakan pemerataan lapangan usaha sekaligus meningkatkan pendapatan masyarakat [6].

Adapun tujuan dari Badan Usaha Milik Desa (BUM Des) sebagai berikut[5]: 1Meningkatkan perekonomian desa; 2 Meningkatkan pendapatan asli desa; 3 Meningkatkan pengolahan potensi desa sesuai dengan kebutuhan masyarakat; 4 Menjadi tulang punggung pertumbuhan dan pemerataan ekonomi pedesaan.

Stakeholder ideal yang terlibat dalam pengelolaan BUM Des adalah Pemerintah Kabupaten dan Pemerintah Desa, Dewan Komisaris, Bagian Keuangan, Manajer BUMDes, Sekretaris, Bendahara, Karyawan[5]. Dalam penelitian ini melibatkan empat stakeholder pokok yaitu Manajer BUMDes, Sekretaris, Bendahara, Karyawan. Adapun kajian literatur tentang penelitian sebelumnya ditunjukkan pada Tabel 1.

Tabel 1

Kajian Literatur Penelitian Sebelumnya

\begin{tabular}{|l|l|l|}
\hline No & Judul Penelitian & Kesimpulan \\
\hline 1 & $\begin{array}{l}\text { Peran badan usaha milik } \\
\text { desa (bumdes) Dalam } \\
\text { meningkatkan } \\
\text { kesejahteraan masyarakat } \\
\text { desa } \\
\text { Berdasarkan uu no. 6 } \\
\text { tahun 2014 tentang desa } \\
\text { (Studi Kasus di BUMDes } \\
\text { Tirta Mandiri Klaten)[7] }\end{array}$ & $\begin{array}{l}\text { Pestingnya peran BUM } \\
\text { masyarakat }\end{array}$ \\
\hline 2 & $\begin{array}{l}\text { Dampak Kegiatan Badan } \\
\text { Usaha Milik Desa (Bum } \\
\text { Des) Bagi Masyarakat } \\
\text { Desa Bareng Kecamatan } \\
\text { Sugihwaras Kabupaten } \\
\text { Bojonegoro[8] }\end{array}$ & $\begin{array}{l}\text { Pentingnya peran BUM } \\
\text { Des dalam kesejahteraan } \\
\text { masyarakat }\end{array}$ \\
\hline 3 & $\begin{array}{l}\text { Perancangan Aplikasi } \\
\text { "Village } \\
\text { Entrepreneurship” } \\
\text { Untuk Meningkatkan } \\
\text { Pengelolaan Badan } \\
\text { Usaha Milik Desa (Bum } \\
\text { Des)[4] }\end{array}$ & $\begin{array}{l}\text { Permasalahan } \\
\text { transparansi Keuangan }\end{array}$ \\
\hline 4 & $\begin{array}{l}\text { Pengembangan Desa } \\
\text { Mandiri Melalui } \\
\text { Pengelolaan Badan } \\
\text { Usaha Milik Desa } \\
\text { (bumdes) [3] }\end{array}$ & $\begin{array}{l}\text { Permasalahan BUM Des } \\
\text { dalam Pengelolaan aspek } \\
\text { permodalan, aspek } \\
\text { kelembagaan, aspek } \\
\text { sumber daya }\end{array}$ \\
\hline
\end{tabular}

\section{METODOLOGI PENELITIAN}

Adapun metode penelitian yang dilakukan menggunakan metode prototype. Metode ini ditunjukkan pada gambar 1 [9].

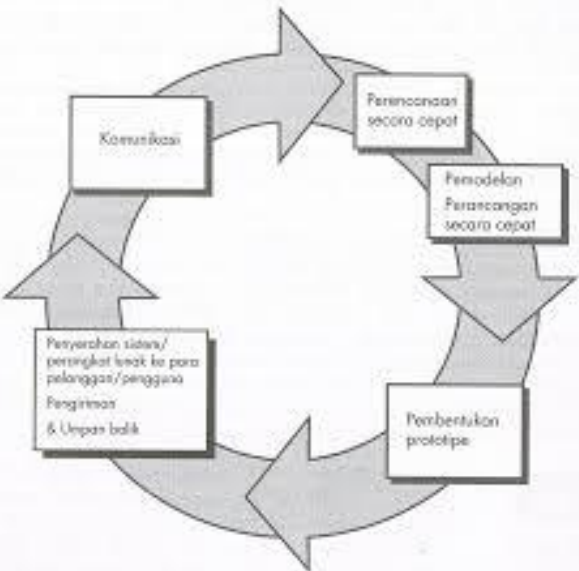

Gambar 1 Paradigma Pembuatan Prototype

Metode yang digunakan adalah metode prototype. Metode ini cocok digunakan untuk mengembangkan suatu perangkat yang akan dikembangkan kembali. Berikut adalah langkah tahapan metode prototype[9] yaitu Komunikasi dan pengumpulan data awal, yaitu pengumpulan dan analisis kebutuhan pengguna. Dalam hal ini tim pengembang berkomunikasi dengan para pengurus BUM Des dan masyarakat. Adapun cara yang digunakan adalah dengan mempelajari keseluruhan bum des yang sudah berjalan dengan baik. Contoh yang diambil adalah BUM Des Tirta Mandiri, Desa Ponggok, Kecamatan Polanharjo, Kabupaten Klaten dan BUMDes Multianggaluku Mandiri di Desa Kalukubula Kabupaten Sigi Provinsi Sulawesi tengah dan beberapa BUM Des yang baru berjalan atau mau membentuk seperti di desa pakiskembar, sumberpasir dan pakisjajar, kecamatan pakis, kabupaten malang dengan segala permasalahannya. Langkah berikutnya adalah Perencanaan secara cepat, yaitu pembuatan desain antarmuka secara umum dirancang dalam permodelan dilanjutkan dengan Pembentukan prototipe dan pengujian hasil atau umpan balik untuk memperhalus spesifikasi kebutuhan. Dalam umpan balik menggunakan pengujian kegunaan[9]

Dalam pengujian aplikasi dilakukan dengan metode skala likert dengan 30 responden dan teori pengujian kegunaan [9].Adapun demografi responden ditunjukkan pada Tabel 2.

Tabel 2

Demografi Responden

\begin{tabular}{|l|l|l|}
\hline No & Nama Desa & Jumlah responden \\
\hline 1 & Desa pakisjajar & 10 \\
\hline 2 & Desa pakiskembar & 10 \\
\hline 3 & Desa sumberpasir & 10 \\
\hline
\end{tabular}

Dalam pengujian sistem, dilakukan pengujian kegunaan [6]. Adapun item yang diuji adalah personalisasi. Pengujian elemen ini ditujukan untuk mengetahui umpan balik dari desain purwarupa yang dibuat untuk menentukan sejauh mana antarmuka aplikasi web mempermudah hidup pengguna dalam hal kebutuhan dalam operasional kegiatan 
BUM Des serta pengawasannya nantinya. Selain itu, kebutuhan fungsional sistem dirangkum pada Tabel 3.

Tabel 3

Kebutuhan Fungsional

\begin{tabular}{|c|c|c|c|}
\hline $\begin{array}{l}\mathbf{N} \\
\mathbf{0}\end{array}$ & $\begin{array}{l}\text { Kebutuhan } \\
\text { fungsional }\end{array}$ & Fungsi & Aktor \\
\hline 1 & Kerjasama & $\begin{array}{l}\text { Pada navigasi kerjasama, } \\
\text { terdapat daftar } \\
\text { perusahaan, perorangan } \\
\text { yang melakukan } \\
\text { kerjasama dengan unit } \\
\text { BUM Des. Berisi tentang } \\
\text { identitas pihak yang } \\
\text { melakukan kerjasama, } \\
\text { tanggal mulai dan } \\
\text { berakhir kerjasama serta } \\
\text { surat perjanjian }\end{array}$ & $\begin{array}{l}\text { 1. Manager Bum } \\
\text { Des } \\
\text { 2. Sekretaris Bum } \\
\text { Des } \\
\text { 3. Bendahara } \\
\text { Bum Des }\end{array}$ \\
\hline 2 & Kegiatan & $\begin{array}{l}\text { Pada navigasi kegiatan, } \\
\text { berisi tentang kegiatan } \\
\text { setiap acara di unit BUM } \\
\text { Des dan notifikasi } \\
\text { kegiatan yang akan } \\
\text { dilaksanakan diurutkan } \\
\text { berdasarkan tanggal } \\
\text { pelaksanaan. }\end{array}$ & $\begin{array}{l}\text { 1. Manager Bum } \\
\text { Des } \\
\text { 2. Sekretaris Bum } \\
\text { Des } \\
\text { 3. Bendahara } \\
\text { Bum Des } \\
\text { 4. Pegawai }\end{array}$ \\
\hline 3 & $\begin{array}{l}\text { Laporan } \\
\text { Keuangan }\end{array}$ & $\begin{array}{l}\text { Pada navigasi lapora } \\
\text { keuangan, dibagi menjadi } \\
\text { dua hal yaitu laporan } \\
\text { tahunan dan diagram per } \\
\text { bulan pada tahun terbaru. } \\
\text { Pada masing-masing } \\
\text { laporan pengeluaran bias } \\
\text { dilengkapi dokumen } \\
\text { pendukung seperti nota } \\
\text { da nada kewajiban } \\
\text { mengisi identitas } \\
\text { pembelanjaan minimal } \\
\text { alamat dan kontak person }\end{array}$ & $\begin{array}{l}\text { 1. Manager Bum } \\
\text { Des } \\
\text { 2. Bendahara }\end{array}$ \\
\hline 4 & Permasalahan & $\begin{array}{l}\text { Pada navigasi } \\
\text { permasalahan, dibagi } \\
\text { menjadi dua hal yaitu } \\
\text { kumpulan permasalahan } \\
\text { pertahun dan tambah } \\
\text { laporan permasalahan }\end{array}$ & $\begin{array}{l}\text { 1. Manager Bum } \\
\text { Des } \\
\text { 2. Sekretaris Bum } \\
\text { Des } \\
\text { 3. Bendahara } \\
\text { Bum Des } \\
\text { 4. Pegawai } \\
\end{array}$ \\
\hline 5 & Chatting & $\begin{array}{l}\text { Pada navigasi chatting, } \\
\text { berisi tentang obrolan } \\
\text { atau percakapan antar } \\
\text { pengurus. }\end{array}$ & $\begin{array}{l}\text { 1. Manager Bum } \\
\text { Des } \\
\text { 2. Sekretaris Bum } \\
\text { Des } \\
\text { 3. Bendahara } \\
\text { Bum Des } \\
\text { 4. Pegawai } \\
\end{array}$ \\
\hline 6 & $\begin{array}{l}\text { Transaksi } \\
\text { Harian }\end{array}$ & $\begin{array}{l}\text { Pada navigasi, transaksi } \\
\text { harian berisi keuangan } \\
\text { secara harian dan bukti } \\
\text { dokumen pendukung } \\
\text { seperti nota dll }\end{array}$ & $\begin{array}{l}\text { 1. Pegawai } \\
\text { 2. Sekretaris Bum } \\
\text { Des }\end{array}$ \\
\hline
\end{tabular}

\section{HASIL PERANCANGAN DAN PENGUJIAN APLIKASI}

A. Use case Diagram Aplikasi

Adapun gambaran visualisasi sistem yang terbentuk ditunjukkan pada gambar 3

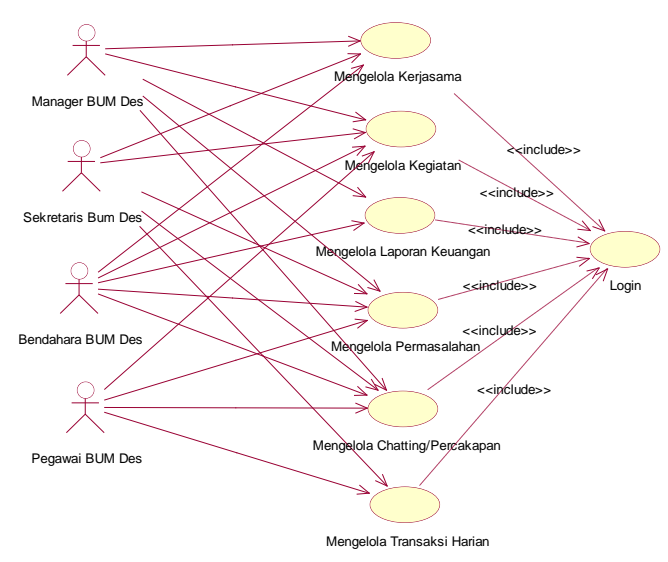

Gambar 3 Use case Aplikasi

\section{B. Hasil Antarmuka}

Dalam perancangan sistem terdapat empat aktor yaitu Manager Bum Des, Sekretaris Bum Des, Bendahara Bum Des dan Pegawai Bum Des. Masing-masing aktor memiliki previllage dalam sistem.

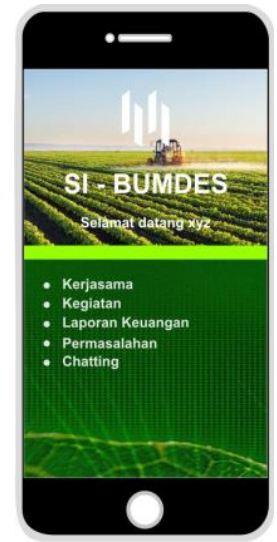

Gambar 3 Antarmuka Manajer Bum Des

Fitur pada masing-masing aktor yang sama yaitu kerjasama, kegiatan, laporan keuangan, permasalahan, chatting dan transaksi harian ditunjukkan pada Gambar 4Gambar 13 . 


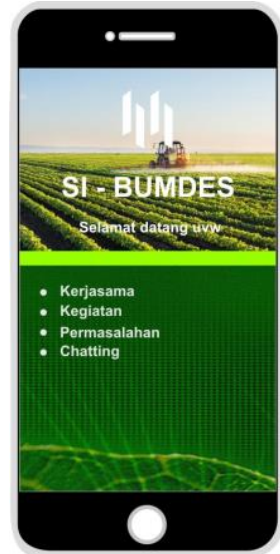

Gambar 4 Antarmuka Sekretaris Bum Des

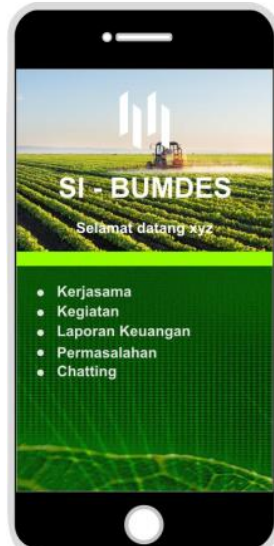

Gambar 5 Antarmuka Bendahara Bum Des

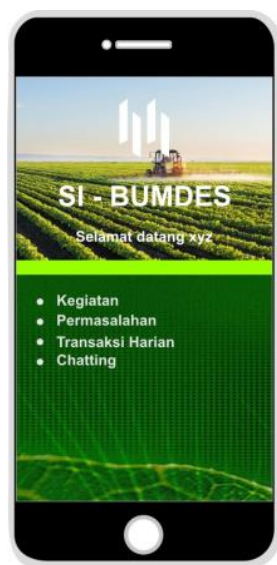

Gambar 6 Antarmuka Pegawai Bum Des

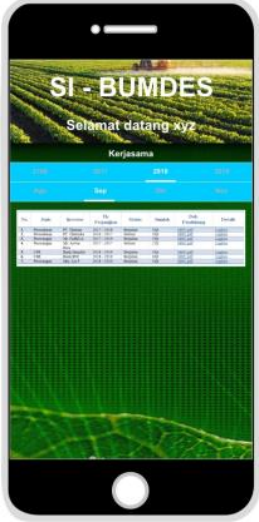

Gambar 7 Antarmuka Kerjasama

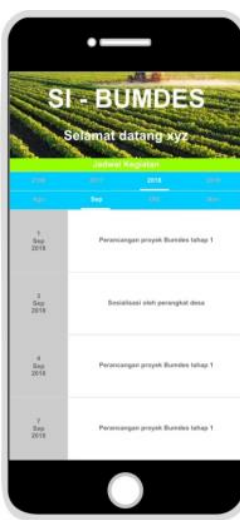

Gambar 8 Antarmuka Jadwal Kegiatan

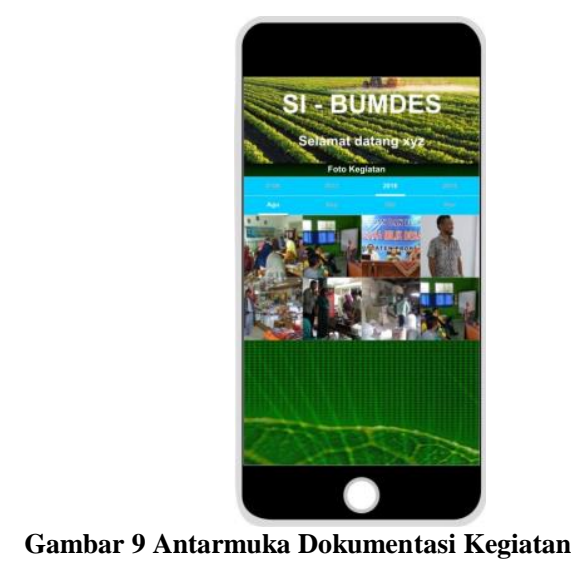

Gambar 9 Antarmuka Dokumentasi Kegiatan 


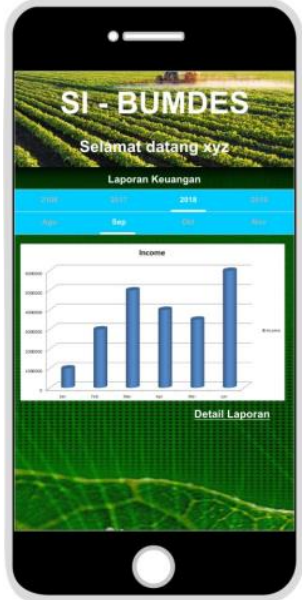

Gambar 10 Antarmuka Laporan Keuangan

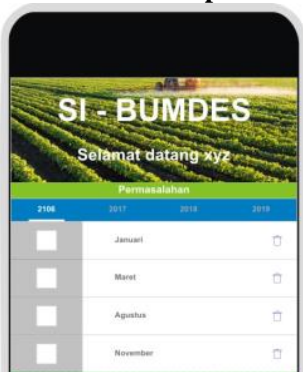

Buat Laporan Masalah

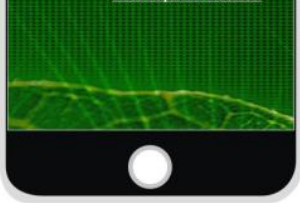

Gambar 11 Antarmuka Permasalahan

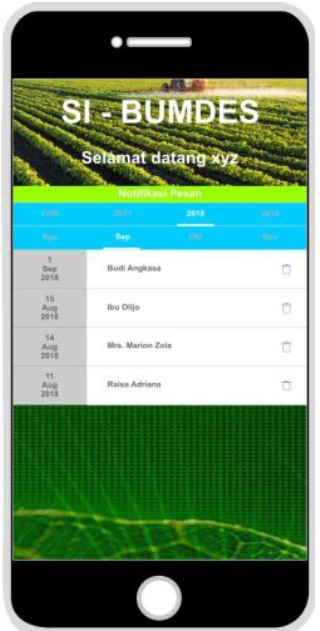

Gambar 12 Antarmuka Pesan (Chatting)

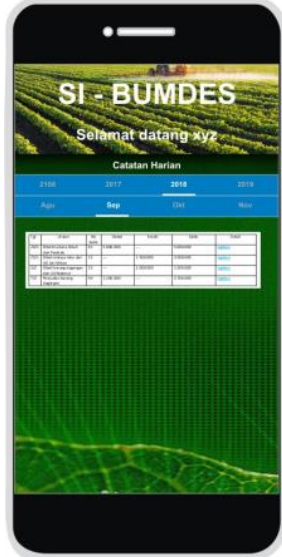

Gambar 13 Antarmuka Transaksi Harian

C. Hasil Pengujian Sistem

A.l Navigasi Kerjasama

1. Bagaimana menurut anda fitur-fitur pengelompokkan kategorisasi pencarian yang ada di menu antarmuka kerjasama (Gambar 7)?, apakah sudah mengakomodir kebutuhan anda?

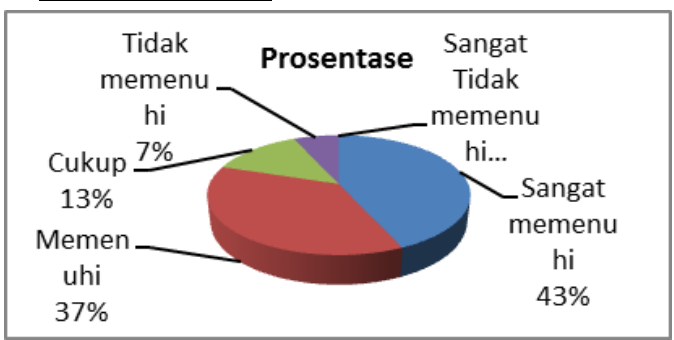

\section{A.2 Navigasi Kegiatan}

1. Bagaimana menurut anda fitur-fitur pengelompokkan navigasi kegiatan yang ada (Gambar 8 dan 9)?apakah sudah mengakomodir kebutuhan anda?

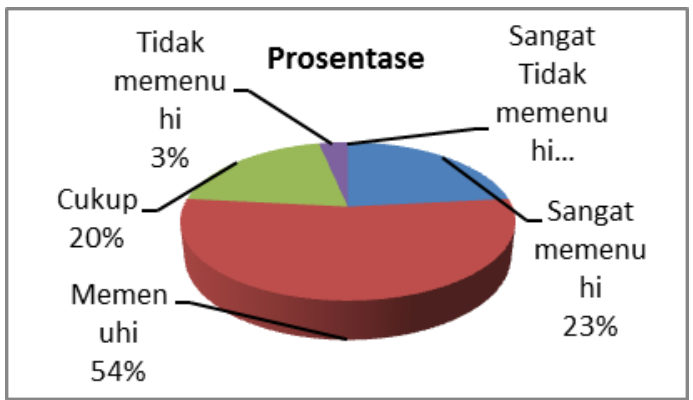

\section{A.3 Navigasi Laporan Keuangan}

1. Bagaimana menurut anda fitur-fitur navigasi laporan keuangan (Gambar 10)?, apakah sudah mengakomodir kebutuhan anda? 


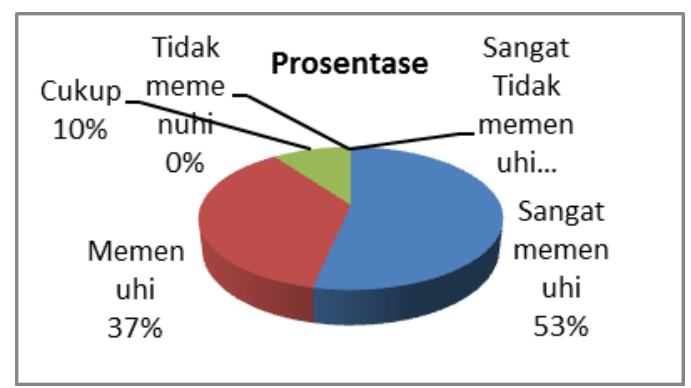

\section{A.4 Permasalahan}

1. Bagaimana menurut anda fitur-fitur navigasi permasalahan (Gambar 11)?, apakah sudah mengakomodir kebutuhan anda?

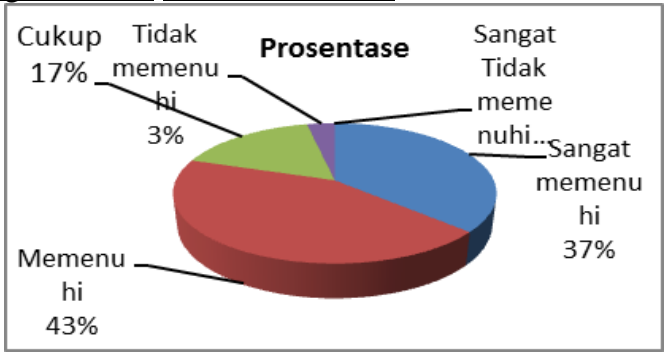

\section{A.5 Chatting}

1. Bagaimana menurut anda fitur-fitur navigasi chatting (Gambar 12)?, apakah sudah mengakomodir kebutuhan anda?

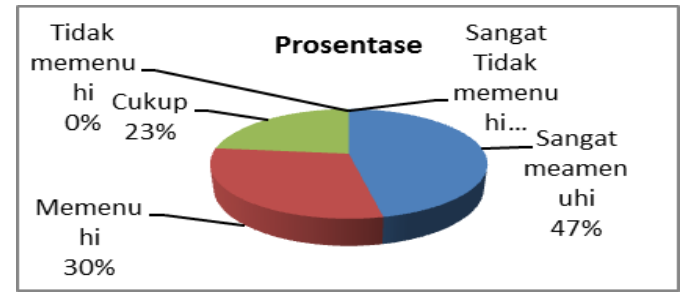

\section{A.6 Transaksi harian}

1. Bagaimana menurut anda fitur-fitur navigasi transaksi harian (Gambar 13)?, apakah sudah mengakomodir kebutuhan anda?

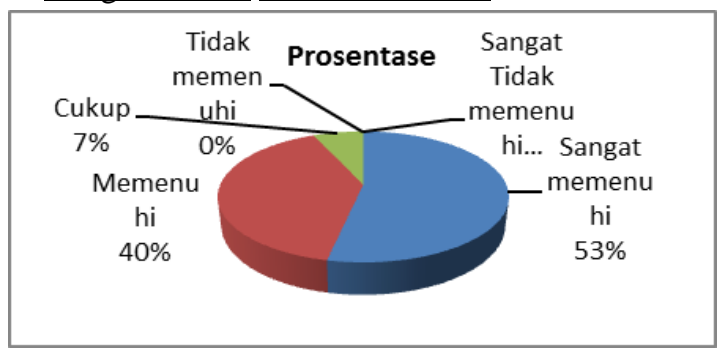

Adapun analisis hasil angket sebagai berikut:

$\mathrm{AK}=\frac{s}{m x n} x 100 \%$

\section{Dengan}

$\mathrm{AK}=$ Prosentase pencapaian angket secara klasikal $\mathrm{s}=$ Jumlah skor dari keseluruhan angket $\mathrm{m}=$ Skor maksimum angket $\mathrm{n}=$ Banyaknya responden

Adapun jumlah prosentase responden yang menjawab sangat memenuhi atau skala lima untuk enam pertanyaan dengan 30 responden adalah 77 responden. Maka perhitungan sebagai berikut[7]:

$$
\begin{aligned}
& \mathrm{AK}=\frac{77 \times 5}{(6 \times 5) \times 30} \times 100 \% \\
& =\frac{385}{900} \times 100 \%
\end{aligned}
$$

\section{$=42,77 \%$}

Dari perhitungan diatas bisa diambil kesimpulan yang menjawab skala 5 yaitu sangat memenuhi sebesar $42,77 \%$.

Jumlah prosentase responden yang menjawab memenuhi atau skala 4 untuk enam pertanyaan dengan 30 responden adalah 72 responden. Maka perhitungan sebagai berikut:

$$
\mathrm{AK}=\frac{72 \times 4}{(6 \times 4) \times 30} \times 100 \%
$$$$
=\frac{288}{720} x 100 \%
$$

$=40 \%$

Dari perhitungan diatas bisa diambil kesimpulan yang menjawab skala 4 yaitu memuaskan sebanyak $40 \%$.

Kesimpulan secara umum diambil dari menggabungkan prosentase responden yang menjawab secara umum skala 5 dan skala 4 yaitu sebesar 82,77\%. Hal ini menunjukkan hasil umpan balik yang dianggap sangat positif.

\section{KESIMPULAN DAN SARAN}

A. Kesimpulan

Hasil timbal balik rancangan aplikasi pengawasan keuangan BUM Des sebesar $82,77 \%$ dengan penggabungan skala 4 dan skala 5 dengan indicator sangat memenuhi dan memenuhi sehingga bisa diambil kesimpulan hasil pengujian terhadap sistem yang dibuat sangat positif

\section{B. Saran}

Aplikasi ini dikembangkan lagi pada sisi antarmuka dengan menyebar lebih banyak kuesioner ke desa-desa yang sudah menjalankan BUM Des dan elemen pengujian diperbanyak.

\section{UCAPAN TERIMA KASIH / ACKNOWLEDGMENT}

Penelitian ini secara finansial didanai oleh Kementerian Riset, Teknologi, dan Pendidikan Tinggi 
(Kemenristekdikti) melalui program hibah Penelitian Dosen

Pemula (PDP) tahun pelaksanaan 2018

\section{REFERENSI}

[1] Anonym, Undang-Undang Nomor 32 Tahun 2004 Tentang Pemerintahan Daerah, 2004.

[2] Badan Pusat Statistik Jakarta Pusat, Persentase Penduduk Miskin Menurut Provinsi Tahun 2013-2016. Semarang : Badan Pusat Statistik, 2017.

[3] Agunggunanto, E. Y., Arianti, F., Kushartono, E. W., \& Darwanto, D. (2016). PENGEMBANGAN DESA MANDIRI MELALUI PENGELOLAAN BADAN USAHA MILIK DESA (BUMDes). Jurnal Dinamika Ekonomi \& Bisnis, 13(1).

[4] Farokhah, L., \& Sapoetra, Y. A. (2018, September). PERANCANGAN APLIKASI "VILLAGE ENTREPRENEURSHIP" UNTUK MENINGKATKAN PENGELOLAAN BADAN USAHA MILIK DESA (BUM DES). In Seminar Nasional Sistem Informasi (SENASIF) (Vol. 2, No. 1, pp. 1073-1082).

[5] Buku panduan pendirian dan pengelolaan badan usaha milik desa (BUM Des, Departemen Pendidikan Nasional Pusat kajian dinamika system pembangunan(PKDSP) Fakultas Ekonomi Universitas Brawijaya: Malang, ), 2007.

[6] Ridlwan, Z. (2014). Urgensi Badan Usaha Milik Desa (BUMDes) dalam Pembangunan Perekonomian Desa.

Fiat Justisia Jurnal Ilmu Hukum, 8(3), 424-440.

[7] Sagita, G. L., Mutimatun, N. A., \& SH, M. (2017). Peran Badan Usaha Milik Desa (Bumdes) Dalam Meningkatkan Kesejahteraan Masyarakat Desa Berdasarkan Uu No. 6 Tahun 2014 Tentang Desa (Studi Kasus di BUMDes Tirta Mandiri Klaten)(Doctoral dissertation, Universitas Muhammadiyah Surakarta).

[8] Syukran, A. (2016). DAMPAK KEGIATAN BADAN USAHA MILIK DESA (BUM Desa) BAGI MASYARAKAT DESA BARENG KECAMATAN SUGIHWARAS KABUPATEN BOJONEGORO. Publika, 4(4).

[9] R. S. Pressman, Rekayasa Perangkat Lunak, Buku 1 Edi. Yogyakarta: Andi Publisher, 2012.

[10] Fitria, V. A. (2016). Peningkatan Efektifitas Pembelajaran Matematika dengan Metode Kooperatif Tipe Stad di STMIK Asia Malang (Studi Kasus Pokok Bahasan Integral). Math Didactic: Jurnal Pendidikan Matematika, 2(2), 77-84. 